\title{
THE EFFECT OF SUBJECTIVE FISH SCALE AGEING ON GROWTH AND RECRUITMENT ANALYSES: A CASE STUDY FROM THE UK
}

\author{
Robin S. MUSK ${ }^{1}$, J. Robert BRITTON ${ }^{2 *}$, Stephen N. AXFORD ${ }^{1}$ \\ ${ }^{1}$ National Fisheries Technical Team, Environment Agency, Bristol, UK \\ ${ }^{2}$ National Fisheries Laboratory, Environment Agency, Brampton, Huntingdon, Cambridgeshire, UK
}

Musk R.S., Britton J.R., Axford S.N. 2006. The effect of subjective fish scale ageing on growth and recruitment analyses: a case study from the UK. Acta Ichthyol. Piscat. 36 (1): 81-84.

\begin{abstract}
Re-ageing of scales sampled in 1985 from the population of roach, Rutilus rutilus (L.), of the River Stour, England, revealed a high degree of subjectivity in their ageing, resulting from contrasting interpretations of similar scale features between practitioners. Compared with ages attained in 1985, re-ageing of the scales in 2004 only found agreement $>80 \%$ at ages 1, 2, and 4 years. By age 9 , agreement had dropped to $6 \%$. The re-ageing revealed the presence of year classes that had previously been thought to have already died out and suggested their recruitment strength was associated with water temperatures in the first year of life of cohorts.
\end{abstract}

Keywords: fish, roach, Rutilus rutilus, scales, year class strengths, age misclassification

Determining the age and growth of fish from temperate waters from hard structures is a classical procedure in fisheries science, with scales usually used when a nondestructive process is required. The ability to accurately determine ages from scales is therefore crucial, especially as the data generated are the foundation for determining population growth rates, mortality rates, ages at maturity, recruitment patterns, and production (Ricker 1975, Bagenal and Tesch 1978, Campana 2001)-information integral to the formulation of many fisheries management strategies. Ageing fish from scales is prone to errors arising from the subjective interpretation of their features (Mann and Steinmetz 1985). Interpretation is made difficult when, for example, annuli overlay each other at the scale margin - a common feature of scales taken from older fish - and when false checks are produced during a growth year. These factors may ultimately result in an age misclassification (Beamish 1979, Campana 2001).

This paper reports on a case study regarding the effects of the subjectivity of scale ageing on subsequent growth and recruitment outputs. Research investigating the factors affecting the recruitment of roach, Rutilus rutilus (L.), in the River Stour, Essex, England, between 1969 and 1996 had revealed annually variable recruitment patterns and the infrequent recruitment of strong year classes
(Frear and Cowx 2003). However, slippage of strong year classes between samples was apparent. For example, in the 1985 sample, the 1975 year class was the dominant cohort, but in the 1988 sample, this switched to the 1976 year class, with the 1975 year class comparatively weak. As it was believed that this might have resulted from the initial scale ageing being erroneous (for example, a quality control procedure had not been used), work was initiated to review the original ageing.

The roach scales used in the case study were collected during stock assessment of the River Stour by electric fishing in June 1985. Following capture, fish had been identified, measured (fork length, mm), and scales removed from 625 roach, with these analysed on a projecting microscope to enable age determination. The scales were then placed in individual paper envelopes and held in an archive room at room temperature. Following retrieval of the scales from the archive, their re-ageing commenced in March 2004. The primary reader of the scales was selected on the basis of their vast experience of ageing scales in recent years. A quality control procedure was utilised by employing a secondary reader who checked $10 \%$ of the aged scales. Where disagreement was found, the scale was reviewed to enable consensus to be reached. On completion of the exercise, the parameters $K$ (growth coeffi- 
cient) and $L_{\infty}$ (maximum theoretical length) of the von Bertalanffy growth model (von Bertalanffy 1960) were determined for the original and revised ageing data $(\mathrm{Ba}-$ genal and Tesch 1978). These values were then compared with those derived for 90 roach populations from other rivers in England, with these data available through a stock assessment programme completed in 2004 during which scales from roach were collected, analysed and growth outputs produced. Recruitment was measured using the year-class-strength method of Cowx and Frear (2004).

Results from the re-ageing exercise revealed only $69 \%$ agreement with the original ages (Table 1), with a significant decrease in agreement with age $(r=-0.96, v=8, P<$ 0.001 ). Agreement was only above $80 \%$ at ages 1,2 , and 4 and reduced to $6 \%$ at age 9 . Furthermore, there were roach now aged in the sample at ages between 11 and 13, when the oldest fish was previously aged at 10 . The principal differences between the ages originated from the subjective interpretation of scale features that included false checks and growth close to the scale margin.

The effect of the re-ageing on the von Bertalanffy growth parameters of the roach population was to reveal the population had a lower maximum theoretical length but higher growth coefficient that had been shown previously, although values were within those expected for roach in English rivers (Fig. 1). The effect on the year class strength output was marked (Fig. 2). The recruitment strength of the 1972, 1973, and 1974 year classes was revealed, with the 1975, 1976, and 1979 year classes shown to be stronger than previously thought (Fig. 2). However, the weak year classes identified in the original ageing - the 1977, 1978, and 1982 year classes - remained weak after the re-analysis (Fig. 2). The original year class strength output had revealed there was no relation between roach recruitment and water temperature in the first year of life of the cohort $(r=0.04, v=6, P>0.10$; Fig. 2 ). However, the re-analysis revealed a significant relation between recruitment and water temperature had actually existed ( $r=0.74, v=6, P<0.05$; Fig. 2$)$, similar to other riverine populations of $R$. rutilus in the UK (e.g., Mills and Mann 1985, Britton et al. 2004).

This case study demonstrates that consequences of subjective scale ageing include the production of incorrect age structures and recruitment patterns. This is important, given that assessment of the ecological status of fish fauna within the EU Water Framework Directive includes age structure evaluation (Anonymous 2000). The case study also revealed that ageing of fish from scales should always incorporate a rigorous quality control method, using at least one experienced worker. If used in conjunction with an ageing validation exercise, ageing accuracy would be further improved (Campana 2001). However, despite the availability of validation techniques, they may be overlooked in many stock assessment exercises due to time and budgetary constraints. Notwithstanding this, even the use of validation techniques may be unable to completely eliminate the subjective element of scale ageing and so new techniques to determine recruitment strength during stock as-sessment should be explored that can account for this subjectivity and produce more robust assessments.

\section{ACKNOWLEDGEMENTS}

The authors wish to thank Graeme Peirson, Robin Burrough, and Robin Wyatt of the Environment Agency for their assistance in compiling the data. The opinions expressed in the paper are those of the authors and not their parent organisation.

Table 1

Results of the scale ageing case study for roach from the River Stour, England, sampled in 1985

\begin{tabular}{ccccc}
\hline $\begin{array}{c}\text { Age } \\
\text { (years) }\end{array}$ & $\begin{array}{c}\text { Number of fish } \\
\text { per age class } \\
\text { after the original } \\
\text { ageing (1985) }\end{array}$ & $\begin{array}{c}\text { Number of fish } \\
\text { assigned their original } \\
\text { age class in the } \\
\text { re-ageing (2004) }\end{array}$ & $\begin{array}{c}\text { Percentage agreement } \\
\text { between the original } \\
\text { and re-ageing }\end{array}$ & $\begin{array}{c}\text { Number of fish } \\
\text { per age class } \\
\text { after re-ageing } \\
(2004)\end{array}$ \\
\hline 1 & 13 & 12 & $92 \%$ & 24 \\
2 & 130 & 110 & $85 \%$ & 115 \\
3 & 120 & 92 & $77 \%$ & 104 \\
4 & 129 & 106 & $82 \%$ & 134 \\
5 & 91 & 58 & $64 \%$ & 86 \\
6 & 51 & 15 & $61 \%$ & 33 \\
7 & 34 & 5 & $19 \%$ & 16 \\
8 & 26 & 1 & $6 \%$ & 22 \\
9 & 17 & 2 & $14 \%$ & 22 \\
10 & 14 & - & - & 4 \\
11 & 0 & - & - & 2 \\
13 & 0 & - & $69 \%$ & 625 \\
\hline
\end{tabular}




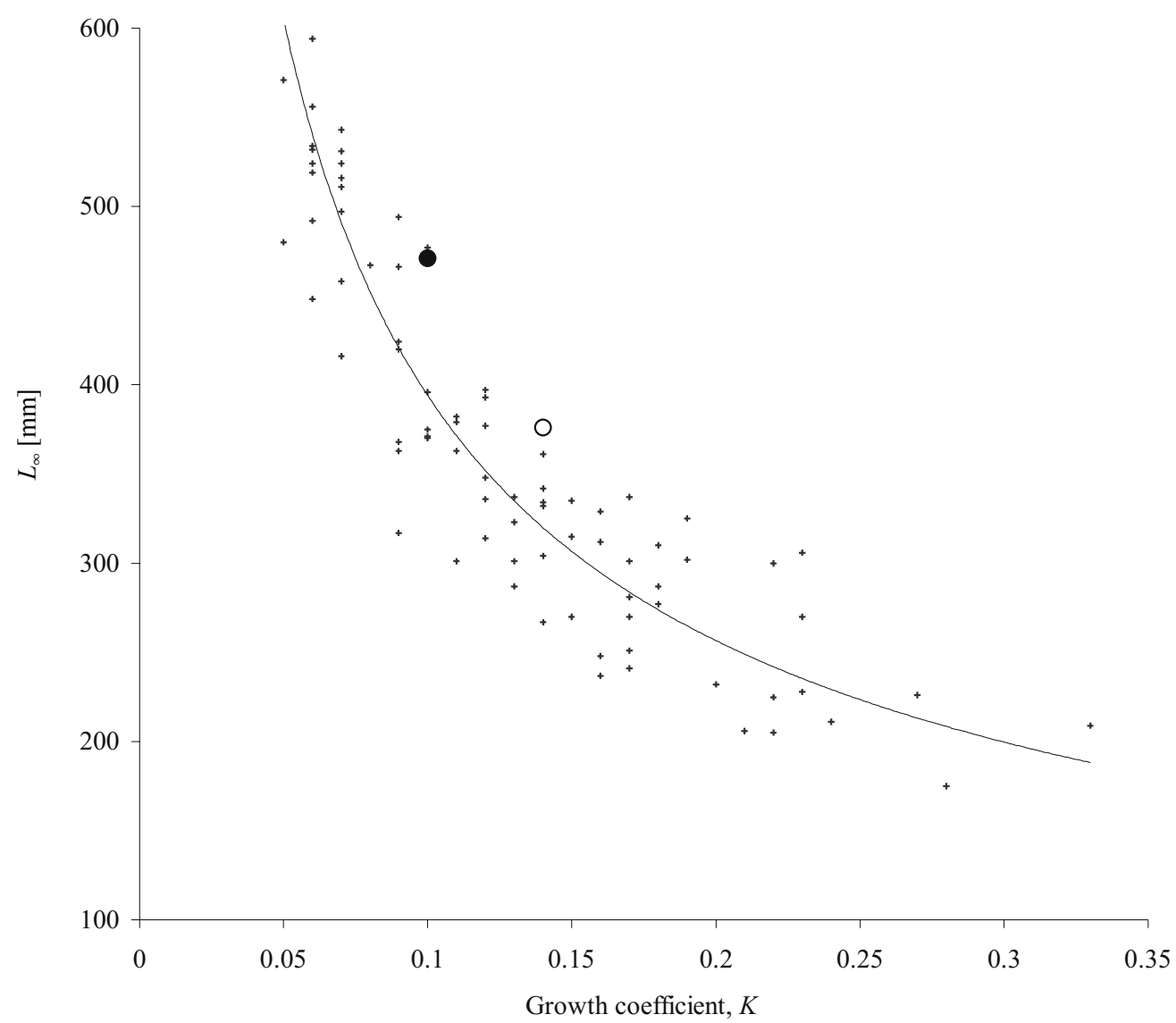

Fig. 1. Relation between $L_{\infty}$ and the growth coefficient $K$ of the von Bertalanffy growth model for roach in rivers in England (+), with comparison to the parameters derived for River Stour roach in the original scale ageing $(\bullet)$ and the re-ageing exercise $(O)$

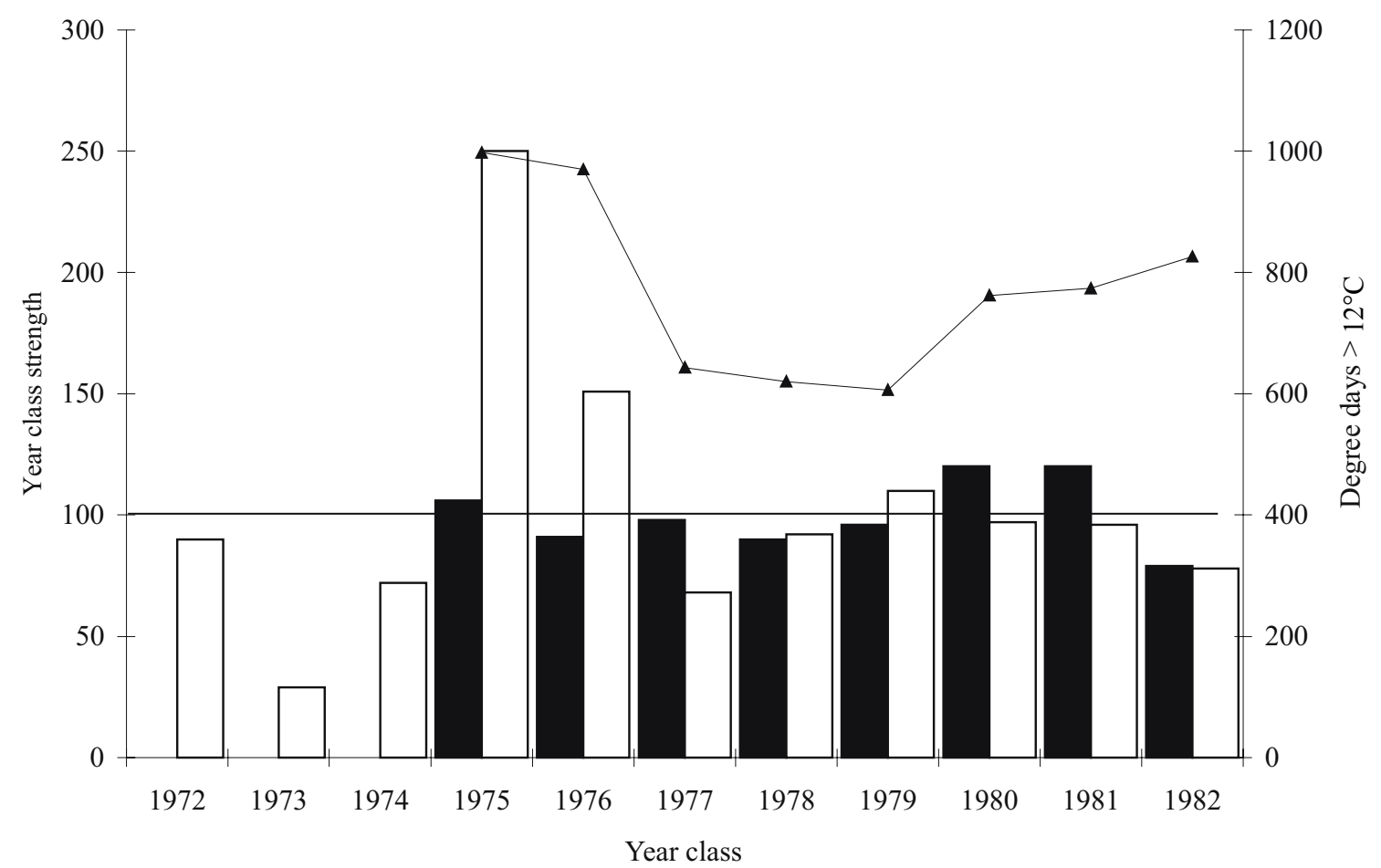

Fig. 2. Difference in the year class strengths output for roach in the River Stour, England, from the original ageing in 1985 (black columns) and the re-ageing completed in 2004 (white columns), with comparison to water temperature, expressed as the number of degree-days $>12^{\circ} \mathrm{C}(\boldsymbol{\Delta})$. The horizontal black line delineates a strong year class from a weak year class 


\section{REFERENCES}

Anonymous 2000. Directive 2000/60/EC of the European Parliament and of the council of 23 October 2000 establishing a framework for community action in the field of water policy. Official Journal of the European Communities L 327 : $1-72$.

Bagenal T.B., Tesch F.W. 1978. Age and growth. Pp. 101-136 In: Bagenal, T.B. (ed.) Methods for the assessment of fish production in fresh waters. Blackwell Scientific Publications, Oxford.

Beamish R.J. 1979. New information on the longevity of Pacific ocean perch (Sebastes alutus). Journal of the Fisheries Research Board of Canada 36: 1395-1400.

Bertalanffy L. von 1960. Principles and theory of growth. Pp 137-259. In: Nowinski W.W. (ed.) Fundamental aspects of normal and malignant growth. Elsevier, Amsterdam.

Britton J.R., Axford S.N., Cowx I.G., Frear P.A. 2004. An overview of recruitment patterns of roach Rutilus rutilus (L.) between 1969 and 2001 in the rivers of England and their influence on population abundance. Ecohydrology and Hydrobiology 4: 91-102.

Campana S.E. 2001. Accuracy, precision and quality control in age determination, including review of the use and abuse of age validation methods. Journal of Fish Biology 59: 197-242.
Cowx I.G., Frear P.A. 2004. Assessment of year class strength in freshwater recreational fish populations. Fisheries Management and Ecology 11: 117-123.

Frear P.A., Cowx I.G. 2003. Factors affecting coarse fish recruitment: Phase II: Examination and analysis of existing Environment Agency data. Environment Agency R\&D Publication W2 048. The Stationery Office, London.

Mann R.H.K., Steinmetz B. 1985. On the accuracy of age determination using scales from rudd, Scardinius erythrophthalmus (L.), of known age. Journal of Fish Biology 26: 621-628.

Mills C.A., Mann R.H.K. 1985. Environmentally induced fluctuations in year class strength and their implications for management. Journal of Fish Biology 27 (Suppl. A): 209-226.

Ricker W.E. 1975. Computation and interpretation of biological statistics of fish populations. Bulletin of the Fisheries Research Board of Canada 191: 1-382. 